
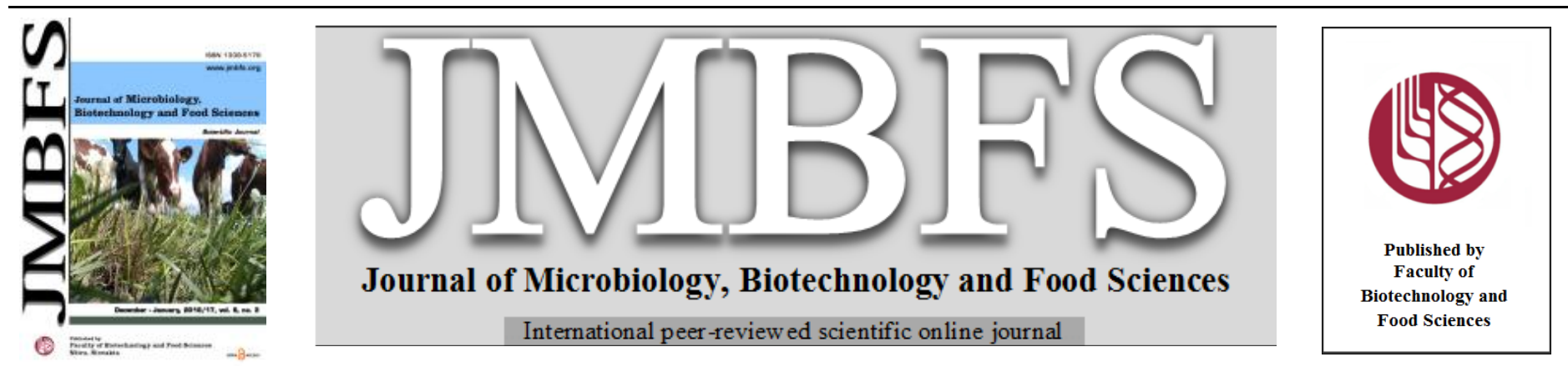

\title{
ENHANCED PRODUCTION OF SINGLE CELL PROTEIN FROM M. capsulatus (BATH) GROWING IN MIXED CULTURE
}

\author{
Jemila J. Nunes*, Brian Aufderheide, Devatie M. Ramjattan, Renuka Dass
}

Address(es): Jemila James Nunes,

The University of Trinidad and Tobago, Process Engineering Department, Esperanza Road, Brechin Castle, Couva, Trinidad, West Indies, Phone number: +1(868) 6428888 Ext. 32283.

*Corresponding author: jemila.james@utt.edu.tt

doi: 10.15414/jmbfs.2016/17.6.3.894-899

\section{ARTICLE INFO}

Received 25. 2. 2016

Revised 12. 8. 2016

Accepted 7. 9. 2016

Published 1. 12. 2016

Regular article

OPEN $\partial_{\text {ACCESS }}$

\section{ABSTRACT}

The growing global demand for nutritional protein means that a sustainable source such as Single Cell Protein from Methylococcus capsulatus (Bath) can become a potential replacement for fishmeal and other animal feeds. Improving biomass concentrations using statistical optimization during synergistic fermentations with a mixed consortium of the three heterotrophic bacteria Alcaligenes acidovorans, Aneurinibacillus danicus, and Brevibacillus sp. can increase the feasibility of the industrial process. The medium components $\mathrm{Mg}^{2+}, \mathrm{Ca}^{2+}, \mathrm{Fe}^{3+}, \mathrm{Cu}^{2+}, \mathrm{PO}_{4}{ }^{2-}, \mathrm{NO}_{3}{ }^{-}, \mathrm{MoO}_{4}{ }^{2-}$, trace metals, and process temperature were screened using a two-level Plackett-Burman Design in shake flasks which resulted in $\mathrm{Cu}^{2+}$ being the only significant factor. The optimum level of $\mathrm{CuSO}_{4} \cdot 5 \mathrm{H}_{2} \mathrm{O}$ was found to be $40 \mu \mathrm{M}$ using One Factor Response Surface Methodology, which was three times higher than the typical values of $\mathrm{Cu}^{2+}$ used previously. These combined strategies led to a $265 \%$ increase in biomass, with final cell concentration of $10.3 \mathrm{~g} / \mathrm{L}$, up from $2.8 \mathrm{~g} / \mathrm{L}$ in fed batch fermentations over 48 hours. The heterotrophic bacteria did not grow on NMS or methane but increased biomass concentration when added to M. capsulatus (Bath) cultures.

Keywords: Methylococcus capsulatus (Bath), Heterotrophic bacteria, Single Cell Protein, Plackett-Burman, Response Surface Methodology

\section{INTRODUCTION}

Single Cell Protein (SCP) from M. capsulatus (Bath), which is cell biomass containing $70 \%$ protein, has been produced as a protein supplement for various animal feed applications. There is renewed interest in the industrial production of SCP since global food and protein demands are projected to rise significantly by 2050 in line with population growth (Alexandratos \& Bruinsma, 2012; United Nations 2012). Its application as a solution to the impending world protein shortage depends on the development of the industrial bioprocess, which includes reactor design, efficient utilization of substrates, and medium development.

The fermentation of M. capsulatus (Bath) is conducted either as a monoculture or in a mixed culture with heterotrophic bacteria, and involves the use of Nitrogen Mineral Salts (NMS) medium and the input of air, natural gas, and carbon dioxide (Eccleston \& Kelly, 1972; Stanley \& Dalton 1982). A previous study (Harwood \& Pirt, 1972) attempted to increase biomass concentrations from $M$. capsulatus (Bath) in a monoculture in bench scale experiments by investigating the effects of several ions, trace metals, and process parameters on biomass concentration. However, maximum cell concentration never increased beyond 0.4 $\mathrm{g} / \mathrm{L}$. Values for maximum cell concentration from other studies (Carlsen, Joergensen, \& Degn, 1991; Furigo \& Jorgensen, 1993; Larsen \& Dalton, 1986; Leak \& Dalton, 1986; Zhivotchenko, Nikonova, \& Jorgensen, 1995) never exceeded a maximum of $6 \mathrm{~g} / \mathrm{L}$ under various conditions. There has never been any attempt to optimize the medium for $M$. capsulatus (Bath) fermentations where heterotrophic bacteria are included.

The use of a mixed bacterial culture was found to be critical in the industrial production process used by Norferm Danmark A/S where three heterotrophic bacteria - DB 3 (Alcaligenes acidovorans), DB 4 (Aneurinibacillus danicus), and DB 5 (Brevibacillus sp.) - would "constantly invade" M. capsulatus cultures (Bothe et al., 2002). This study identified the heterotrophic strains, quantified the growth of the bacteria on substrates found in supernatant fractions, and determined that all strains were non-toxic. DB 3 and DB 4 exhibited high growth on acetate, DB 5 was best at reducing free amino acids, and all strains reduced total organic carbon. However, there was no indication from this study that these heterotrophs acted on the oxidation products of hydrocarbons other than ethane. Previous studies have indicated that the heterotrophic bacteria act in synergy with an obligate methylotroph like $M$. capsulatus (Bath) by scavenging the oxidized by-products of natural gas, as well as the metabolic by-products of the obligate methylotroph, thereby bringing a measure of stability to the overall process while maximizing growth rates and yield coefficients (Harrison, 1978; Linton \& Buckee, 1977). Thus it is important that the media for this process is optimized as a mixed culture since the presence of the heterotrophic bacteria is crucial for its industrial application.

In order to increase the volumetric productivity of SCP during continuous fermentations, there is a requirement for achieving high cell concentrations during the batch and fed-batch stages. The first optimization step must therefore involve improving the composition of the growth medium and optimizing other process parameters for achieving maximum cell concentrations in the shortest possible time. The simplest strategy for medium development is the 'one at a time' method where one component is varied while the others are kept constant. In this way, the individual effects of each component on the medium are determined, but it can be time-consuming due to the large number of experiments involved (Kennedy \& Krouse, 1999). A better strategy for optimization is the Response Surface Methodology (RSM) where a functional relationship between the medium components and the response of interest can be determined (Khuri \& Mukhopadhyay, 2010). It involves the use of a design matrix for screening along with an optimization technique in which a mathematical model is used to determine the optimized medium composition (Kennedy \& Krouse, 1999).

Typically, a first-degree design (full or partial factorial) is used to screen and determine the significance of the factors. The most widely used screening method is the Plackett-Burman Design (PBD) which is a 2-level factorial design where the factor levels are set to a high and low value. In PBD, the number of experimental runs $n$ is equal to $k+1$, which is the same as the number of factors in the model, and the design only applies when $n$ is a multiple of 4 . This design does not account for interaction effects but if the levels are chosen correctly, it is a useful screening tool for determining the most significant factors, thereby reducing the number of factors to be optimized. The first-degree design is then followed by a second-degree design (single or multi-factor) which determines the optimum settings of each factor that result in either the maximum or minimum response over a certain range of interest. The most popular second-order design is Central Composite Design (CCD) which involves a $2^{\mathrm{k}}$ factorial design with 
factors set at five levels and the addition of an axial portion consisting of $2 k$ axial points chosen based on the distance of the axial parameter $(\alpha)$ from the design center. In the case where the screening process results in only one factor being significant, a One Factor Response Surface Methodology (OFRSM) can be used to determine the optimal level of the variable.

OFRSM has been used to model methylene blue degradation (Attarchi, Montazer, \& Toliyat, 2013), dynamic viscosity of a micro-emulsion (Jeirani $\boldsymbol{e}$ al., 2013), and to optimize biosurfactant production (Chen $\boldsymbol{e t}$ al., 2012). These combined RSM techniques have been used for a wide range of applications including enhancing biomass from fungi (Zhang et al., 2014), microalgae (Zarate-Chaves et al., 2013), and yeast (Li et al., 2009). It has also been used to enhance ethanol production (Manwar, Mahadik, \& Paradkar, 2013; Walia $e$ al., 2014), and other high value products (Kosmider et al., 2012; MokhtariHosseini et al., 2009; Yatsyshyn, Fedorovych, \& Sibirny, 2010).

The objective of this study was to increase biomass concentration from $M$. capsulatus (Bath) in a mixed culture with three heterotrophic bacteria using statistical experimental design. This approach has not been previously used to optimize media for production of biomass by this microbe, either in a mono- or mixed culture. PBD was used as a screening tool for the medium components, followed by a second-degree RSM design chosen based on the resultant number of significant factors. Since only one factor was found to be significant, OFRSM was used to determine the optimal level. The predicted response determined from the OFRSM was then validated in shake flasks and fed-batch fermentations over 48 hours.

\section{MATERIALS AND METHODS}

\section{Growth of $M$. capsulatus (Bath)}

The methylotrophic microorganism used in this study was Methylococcus capsulatus (Bath) NCIMB 11132 (NCIMB Ltd. Culture Collection, Aberdeen, Scotland) obtained as freeze-dried vials. The cells were resuscitated using NCIMB Nitrogen Mineral Salts (NMS) Medium 131 (Salts per L: $\mathrm{MgSO}_{4} \cdot 7 \mathrm{H}_{2} \mathrm{O}$ $1.0 \mathrm{~g}, \quad \mathrm{CaCl}_{2} .2 \mathrm{H}_{2} \mathrm{O} \quad 0.26 \mathrm{~g}, \quad \mathrm{KNO}_{3} \quad 1.0 \mathrm{~g}, \mathrm{C}_{10} \mathrm{H}_{12} \mathrm{FeN}_{2} \mathrm{NaO}_{8} \quad 0.0038 \mathrm{~g}$, $\mathrm{Na}_{2} \mathrm{MoO}_{4} \cdot 2 \mathrm{H}_{2} \mathrm{O} 0.00026 \mathrm{~g}, \mathrm{Na}_{2} \mathrm{HPO}_{4} \cdot 2 \mathrm{H}_{2} \mathrm{O} 0.356 \mathrm{~g}, \mathrm{KH}_{2} \mathrm{PO}_{4} 0.026 \mathrm{~g}$ ). Trace metals solution was added at final concentrations: $\mathrm{CuSO}_{4} .5 \mathrm{H}_{2} \mathrm{O} 0.8 \mu \mathrm{M}$, $\mathrm{FeSO}_{4} .7 \mathrm{H}_{2} \mathrm{O} 1.8 \mu \mathrm{M}, \mathrm{ZnSO}_{4} .7 \mathrm{H}_{2} \mathrm{O} 1.4 \mu \mathrm{M}, \mathrm{H}_{3} \mathrm{BO}_{3} 0.24 \mu \mathrm{M}, \mathrm{CoCl}_{2} .6 \mathrm{H}_{2} \mathrm{O} 0.21$ $\mu \mathrm{M}$, EDTA disodium salt $0.67 \mu \mathrm{M}, \mathrm{MnCl}_{2} .4 \mathrm{H}_{2} \mathrm{O} 0.1 \mu \mathrm{M}$, and $\mathrm{NiCl}_{2} .6 \mathrm{H}_{2} \mathrm{O} 0.04$ $\mu \mathrm{M}$. All chemicals were of ACS Analytical grade sourced from SIGMA ALDRICH CO (St. Louis, MO), MALLINCKRODT BAKER (New Jersey, USA), and FISHER SCIENTIFIC (New Jersey, USA). Cells were stored in $15 \%$ glycerol at $-80^{\circ} \mathrm{C}$ and were also maintained on agar plates made from NMS medium with $0.02 \% \mathrm{v} / \mathrm{v}$ methanol added after sterilization. Cells were spread onto the plates aseptically using a vial from glycerol stock, after which the plates were placed in an airtight gas jar and left in an incubator set at $45^{\circ} \mathrm{C}$, under an atmosphere of $\mathrm{CH}_{4}$ : Air: $\mathrm{CO}_{2}$ of 9:9:2. Plates were then stored at $4^{0} \mathrm{C}$ until ready for use.

To prepare seed cultures for experiments, colonies from agar plates were inoculated into $500 \mathrm{~mL}$ baffled shake flasks containing $100 \mathrm{~mL}$ aliquots of NMS medium and $20 \mu \mathrm{L}$ methanol. Each flask was sealed with a two-holed rubber stopper fitted with stainless steel tubing connected to silicone tubing with a sterile filter (Sartorius Midisart 2000) attached at one end to allow sparging with $45 \%$ $\mathrm{CH}_{4}$ and $4.5 \% \mathrm{CO}_{2}$. Both pieces of tubing were clamped and the shake flasks were placed into a digital incubated shaker (ThermoScientific MaxQ Mini SHKE 4450 Digital) at $45^{\circ} \mathrm{C}$ and $180 \mathrm{rpm}$ for 48 hours. Cells were centrifuged at $5000 \mathrm{~g}$ for 10 minutes, after which the cell pellet was re-suspended in NMS medium and used in further experiments. OD at $540 \mathrm{~nm}$ was measured using a ThermoScientific Genesys 6 UV/Visible Spectrophotometer with deionized water as the blank. Dry cell weight was found by vacuum filtering a known volume of cell culture through a Merck Millipore cellulose acetate $0.45 \mu \mathrm{M}$ filter and dried to constant weight.

\section{Growth of heterotrophic bacteria}

For shake flask investigations, the three heterotrophic bacteria - NCIMB 13287 Alcaligenes acidovorans, NCIMB 13288 Aneurinibacillus danicus, and NCIMB 13289 Brevibacillus sp. were added to the culture. A. danicus and Brevibacillus sp. were cultured in $3 \mathrm{~g} / \mathrm{L}$ Yeast extract broth (Lab M) and A. acidovorans was cultured in $3 \mathrm{~g} / \mathrm{L}$ Nutrient broth (Lab M). $50 \mathrm{~mL}$ of each respective media was placed in a $250 \mathrm{~mL}$ shake flask which was fitted with a foam stopper and sterilized at $121^{\circ} \mathrm{C}$ for 15 minutes. Once cooled, the flasks were inoculated with the respective organisms and placed in the shaker at $45^{\circ} \mathrm{C}, 180 \mathrm{rpm}$, for 24 hours The cells were centrifuged, re-suspended in NMS before combining with $M$. capsulatus (Bath) for fermentation. For investigation of heterotrophic growth on NMS, each strain was added to $50 \mathrm{~mL}$ shake flasks containing $10 \mathrm{~mL}$ NMS to a start OD of 0.1. Flasks were sparged with air, methane, and carbon dioxide in the ratio described previously and incubated on the shaker and OD $540 \mathrm{~nm}$ was checked after 24 hours.

\section{Plackett-Burman Design}

Generation of the design matrix and statistical analysis for PBD was done using Minitab 16 (MINITAB Inc.). Media recipes used in previous literature (Table 1) were used to select the high (+) and low (-) levels for each variable. Nine (9) variables (Table 2) were selected as the most relevant to screen using a 12-run PBD (Table 3) for increasing biomass production in the fermentation broth. In the NCIMB medium, $\mathrm{CuSO}_{4} .5 \mathrm{H}_{2} \mathrm{O}$ is only present in a small amount in the trace metal solution. However, it was included here as a major factor since it is included in other fermentation media for growth of $M$. capsulatus (Bath) in varying concentrations. The concentration and composition of the trace metals solution was kept constant but the volume added was modified. In the PBD model, all interactions were ignored and it was assumed that a first order regression model was applicable.

Each run in the design matrix was conducted in $250 \mathrm{~mL}$ shake flasks with $50 \mathrm{~mL}$ of medium corresponding to the specific run in the design matrix and inoculated with $1 \mathrm{~mL}$ of seed culture. Flasks were sparged and placed in an incubated shaker set at the appropriate temperature (either $37{ }^{\circ} \mathrm{C}$ or $45^{\circ} \mathrm{C}$ ) with a shaking speed of $180 \mathrm{rpm}$. After 24 hours, the $\mathrm{OD}_{540}$ was measured. All experiments were carried out at least in triplicate and the results were the average of the replicate experiments with standard error $\leq 5 \%$. The confidence level was set at $95 \%$ and the significant factors were selected based on the $p$-value falling below 0.05 . The Effect (E) of each factor was determined from the regression analysis. The effects of the non-significant variables were used to set the new concentrations of these variables for validation experiments in shake flasks and fed-bath fermentations.

\section{One Factor Response Surface Methodology}

Based on the outcome of the PBD, OFRSM was used to determine the optimum concentration of the significant factor using Design Expert 8.0 (STAT-EASE Inc.). The factor was examined at five concentration levels in an eight run design generated by the statistical software to determine the optimum concentration Shake flasks were prepared as previously described for PBD with the appropriate concentrations of the medium components.

\section{Validation experiments}

All experiments with the optimized NMS medium were performed in shake flasks in triplicate as previously described for 24 hours. The optimized medium was also tested via fed-batch fermentations in a 5L Sartorius B. Braun Biostat B plus fermenter (SARTORIUS STEDIM). Start volume was $2 \mathrm{~L}$ of the optimized NMS medium, with a ten-fold concentrated feed stream of the media at flow-rate $4 \mathrm{~m} \mathrm{~L} / \mathrm{min}$ connected to low flow peristaltic pumps (Watson Marlow 101U/R) for fed-batch operation. $\mathrm{pH}$ was controlled automatically using $1 \mathrm{M}$ solutions of $\mathrm{NaOH}$ and $\mathrm{H}_{2} \mathrm{SO}_{4}$ and temperature was automatically controlled at $43^{\circ} \mathrm{C}$ in the double jacketed vessel. Agitation rates were selected based on achieving a mass transfer coefficient (kLa) value of $0.05 \mathrm{~s}^{-1}$ for $0.5 \mathrm{vvm}$ air in NMS medium (500 $\mathrm{rpm})$, and $0.12 \mathrm{~s}^{-1}(800 \mathrm{rpm})$ for higher cell densities $(3-4 \mathrm{~g} / \mathrm{L})$. kLa was determined using the Hydrogen Peroxide-Catalase Method (Hickman, 1988; Cooke et al., 1991). Air flow rate was set at $0.5 \mathrm{vvm}, \mathrm{CH}_{4}$ at $0.1 \mathrm{vvm}$, and $\mathrm{CO}_{2}$ at 0.0012 vvm. M. capsulatus (Bath) cells and the heterotrophic bacteria were inoculated into the fermenter in the ratio 75:25 respectively, with $A$ acidovaorans comprising $10 \%$ of the mixture, and $7.5 \%$ each of Brevibacillus sp. and A. danicus. All fermentations were stopped after 48 hours with final ODs recorded and compared to ODs at 48 hours for fed-batch fermentations using the un-optimized media. Results were converted to cell concentration $(\mathrm{g} / \mathrm{L})$ using a linear relation for OD versus dry cell weight (DCW) determined using cell suspensions of $M$. capsulatus (Bath)

$O D=2.6184 D C W+2.0139$ 
Table 1 Media compositions for Nitrogen Mineral Salts medium from previous literature

\begin{tabular}{|c|c|c|c|c|c|c|c|c|c|}
\hline Reference & $\begin{array}{c}\text { (Foster \& } \\
\text { Davis, 1966) }\end{array}$ & $\begin{array}{c}\text { (Whittenbury, } \\
\text { Phillips, \& } \\
\text { Wilkinson } \\
\text { 1977) }\end{array}$ & $\begin{array}{c}\text { (Harwood \& } \\
\text { Pirt } \\
\text { 1972) }\end{array}$ & $\begin{array}{c}\text { (Dalton \& } \\
\text { Whittenbury, } \\
\text { 1976) }\end{array}$ & $\begin{array}{c}\text { (Carlsen, } \\
\text { Joergensen } \\
\text { \& \& Degn, } \\
\text { 1991) } \\
\end{array}$ & $\begin{array}{l}\text { (Larsen \& } \\
\text { Dalton } \\
\text { 1986) }\end{array}$ & & $\begin{array}{c}\text { (Furigo \& } \\
\text { Jorgensen, } \\
\text { 1993) }\end{array}$ & $\begin{array}{c}\text { (Zhivotchenk } \\
\text { o, Nikonova, } \\
\text { \& Jorgensen, } \\
\text { 1995) } \\
\end{array}$ \\
\hline Methane \% & 50 & $30-50$ & 50 & 20 & $2.4 \mathrm{~g} / \mathrm{L}$ & Excess & & 40 & 66 \\
\hline Methanol v/v & - & $0.01-0.1(\mathrm{w} / \mathrm{v})$ & - & - & - & - & & - & - \\
\hline \multicolumn{7}{|c|}{ Salt Concentration (g/L) unless otherwise stated } & \multicolumn{3}{|c|}{ Concentration $\mathbf{m M}$} \\
\hline $\mathrm{KNO}_{3}$ & - & 1.0 & - & 1.0 & 1.0 & - & $\mathbf{N H}_{4}^{+}$ & 25 & 20 \\
\hline $\mathrm{NaNO}_{3}$ & 2.0 & - & - & - & - & - & $\mathrm{SO}_{4}{ }^{2-}$ & 12.56 & - \\
\hline $\mathrm{NH}_{4} \mathrm{Cl}$ & - & 0.5 & 0.15 & - & - & - & $\mathrm{PO}_{4}{ }^{3-}$ & 7.81 & - \\
\hline $\mathrm{NH}_{4} \mathrm{NO}_{3}$ & - & - & - & - & - & 1.88 & $\mathrm{Cl}^{-}$ & 1.91 & - \\
\hline $\mathrm{MgSO}_{4} \cdot 7 \mathrm{H}_{2} \mathrm{O}$ & 0.2 & 1.0 & 0.075 & 1.0 & 0.25 & 0.38 & $\mathrm{Mg}^{2+}$ & 1.27 & 0.34 \\
\hline $\mathrm{CaCl}_{2} \cdot 2 \mathrm{H}_{2} \mathrm{O}$ & 0.015 & 0.26 & 0.001 & 0.200 & 0.05 & 0.146 & $\mathbf{K}^{+}$ & 1.86 & - \\
\hline a'FeNaEDDHA & - & 0.004 & - & - & - & - & $\mathrm{Ca}^{2+}$ & 0.94 & 0.59 \\
\hline baFeEDTA & - & - & - & 0.005 & - & - & $\mathrm{Na}^{+}$ & 0.002 & - \\
\hline $\mathrm{FeSO}_{4} .7 \mathrm{H}_{2} \mathrm{O}$ & 0.001 & - & - & - & 0.014 & 0.075 & $\mathrm{Fe}^{3+}$ & 0.018 & 0.031 \\
\hline $\mathrm{Na}_{2} \mathrm{MoO}_{4} \cdot 2 \mathrm{H}_{2} \mathrm{O}$ & - & 0.00026 & - & 0.0002 & 0.001 & 0.0000012 & $\mathrm{Cu}^{2+}$ & $\begin{array}{c}0.008 \\
5\end{array}$ & $0.00037-0.128$ \\
\hline $\mathrm{MoO}_{3}$ & 0.00001 & - & - & - & - & - & $\mathrm{Ni}^{2+}$ & $\begin{array}{c}0.000 \\
05\end{array}$ & - \\
\hline $\mathrm{CuSO}_{4} .5 \mathrm{H}_{2} \mathrm{O}$ & 0.000005 & 0.00075 & 0.0003 & - & 0.0025 & 0.0035 & $\mathrm{Mn}^{2+}$ & $\begin{array}{c}0.000 \\
13\end{array}$ & 0.027 \\
\hline $\mathrm{NaH}_{2} \mathrm{PO}_{4}$ & 0.09 & - & - & - & - & - & $\mathrm{Co}^{2+}$ & $\begin{array}{c}0.000 \\
53\end{array}$ & 0.00071 \\
\hline $\mathrm{Na}_{2} \mathrm{HPO}_{4} .12 \mathrm{H}_{2} \mathrm{O}$ & 0.21 & 01 & 1.2 & 0.33 & - & 0.356 & $\mathrm{Zn}^{2+}$ & $\begin{array}{c}0.001 \\
7\end{array}$ & 0.004 \\
\hline $\mathrm{KH}_{2} \mathrm{PO}_{4}$ & - & 0.1 & 0.7 & 0.26 & 0.13 & 0.26 & $\mathbf{B}^{3+}$ & $\begin{array}{c}0.000 \\
26\end{array}$ & 0.08 \\
\hline Citric Acid & - & - & 0.2 & - & - & - & $\mathbf{M o}^{7+}$ & 0.002 & - \\
\hline Ferric Citrate & - & - & 0.002 & - & - & - & $\mathrm{Mo}^{6+}$ & - & 0.00083 \\
\hline $\mathrm{HCl}$ & - & - & $0.003 \mathrm{ml}$ & - & - & - & $\mathrm{NaOH}$ & - & $22.5-23.5$ \\
\hline $\mathrm{KCl}$ & 0.04 & - & - & - & - & - & $\begin{array}{c}\mathrm{KH}_{2} \mathrm{PO}_{4} \\
\mathrm{NaH}_{2} \mathrm{P} \\
\mathrm{O}_{4} \\
\end{array}$ & - & $\begin{array}{l}2.64 \\
3.28\end{array}$ \\
\hline
\end{tabular}

${ }^{\mathrm{a}} \mathrm{NaFeEDTA}=$ Ethylenediaminetetraacetic acid ferric sodium salt $\mathrm{C}_{10} \mathrm{H}_{12} \mathrm{~N}_{2} \mathrm{NaFeO}_{8}$

${ }^{\mathrm{b}} \mathrm{FeNa}$-EDDHA = "Sequestrene Iron complex" Sodium Ferric ethylenediamine BIS-(2-hydroxyphenylacetate) $\mathrm{C}_{18} \mathrm{H}_{16} \mathrm{O}_{6} \mathrm{~N}_{2} \mathrm{NaFe}$

$\underline{\text { Table } 2 \text { List of variables and their respective coded names for PBD screening }}$

\begin{tabular}{|c|c|c|c|c|}
\hline \multirow{2}{*}{ Variable } & \multirow{2}{*}{$\begin{array}{l}\text { Variable } \\
\text { code }\end{array}$} & \multicolumn{3}{|c|}{ Levels $(\mathrm{g} / \mathrm{L})$} \\
\hline & & Low (-) & $\begin{array}{l}\text { Center point } \\
(0)\end{array}$ & $\begin{array}{l}\text { High } \\
(+)\end{array}$ \\
\hline $\mathrm{KH}_{2} \mathrm{PO}_{4}$ & A & 0.1 & 0.45 & 0.8 \\
\hline $\mathrm{KNO}_{3}$ & B & 1 & 1.5 & 2 \\
\hline $\mathrm{MgSO}_{4} \cdot 7 \mathrm{H}_{2} \mathrm{O}$ & $\mathrm{C}$ & 0.5 & 1 & 1.5 \\
\hline $\mathrm{CaCl}_{2} \cdot 2 \mathrm{H}_{2} \mathrm{O}$ & $\mathrm{D}$ & 0.1 & 0.3 & 0.5 \\
\hline $\mathrm{C}_{10} \mathrm{H}_{12} \mathrm{FeN}_{2} \mathrm{NaO}_{8}$ & $\mathrm{E}$ & 0.005 & 0.05 & 0.1 \\
\hline $\mathrm{CuSO}_{4} .5 \mathrm{H}_{2} \mathrm{O}$ & $\mathrm{F}$ & 0.003 & 0.011 & 0.018 \\
\hline $\mathrm{Na}_{2} \mathrm{MoO}_{4} \cdot 2 \mathrm{H}_{2} \mathrm{O}$ & $\mathrm{G}$ & 0 & 0.0005 & 0.05 \\
\hline Trace Metals $^{\mathrm{a}}$ & $\mathrm{H}$ & 0 & 1 & 2 \\
\hline Temperature $^{\mathrm{b}}$ & I & 37 & 41 & 45 \\
\hline
\end{tabular}

${ }^{\mathrm{a}}$ Trace metals concentrations in $\mathrm{mL} / \mathrm{L}$

${ }^{\mathrm{b}}$ Temperature units $={ }^{0}$ Celcius

Table 3 Variables for PBD (in coded levels) with corresponding $\mathrm{OD}_{540}$ response values for biomass concentration

\begin{tabular}{|c|c|c|c|c|c|c|c|c|c|c|c|c|}
\hline \multirow{2}{*}{ Run \# } & \multicolumn{11}{|c|}{ Coded variables and levels } & \multirow{2}{*}{$\begin{array}{c}\text { Response } \\
\left(\text { OD }_{540}\right)\end{array}$} \\
\hline & $\mathbf{A}$ & B & $\mathbf{C}$ & D & $\mathbf{E}$ & $\mathbf{F}$ & $\mathbf{G}$ & $\mathbf{H}$ & $\mathbf{I}$ & $* \mathbf{J}$ & $* \mathbf{K}$ & \\
\hline 1 & + & - & + & - & - & - & + & + & + & - & + & 0.519 \\
\hline 2 & + & + & - & + & - & - & - & + & + & + & - & 0.320 \\
\hline 3 & - & + & + & - & + & - & - & - & + & + & + & 0.159 \\
\hline 4 & + & - & + & + & - & + & - & - & - & + & + & 0 \\
\hline 5 & + & + & - & + & + & - & + & - & - & - & + & 0.431 \\
\hline 6 & + & + & + & - & + & + & - & + & - & - & - & 0 \\
\hline 7 & - & + & + & + & - & + & + & - & + & - & - & 0.078 \\
\hline 8 & - & - & + & + & + & - & + & + & - & + & - & 0.607 \\
\hline 9 & - & - & - & + & + & + & - & + & + & - & + & 0.120 \\
\hline 10 & + & - & - & - & + & + & + & - & + & + & - & 0.055 \\
\hline 11 & - & + & - & - & - & + & + & + & - & + & + & 0 \\
\hline 12 & - & - & - & - & - & - & - & - & - & - & - & 0.355 \\
\hline
\end{tabular}

RESULTS AND DISCUSSION

\section{Screening of the factors by PBD}

Nine variables were screened according to the PBD experimental runs shown in Table 3 along with the corresponding OD response values for each of the runs. The results show that runs 1,5 , and 8 gave the maximum yields while some runs showed no growth, or the combination of salts caused precipitation (represented as ' 0 '). These results were then subjected to regression analysis (Table 4) where the effects of each factor are shown. Most effects were slightly positive, meaning that a higher level would produce a more favorable response while for $\mathrm{CuSO}_{4} .5 \mathrm{H}_{2} \mathrm{O}, \mathrm{KNO}_{3}$, and temperature, the effects were negative indicating that a value lower than the maximum level would be more favorable.

Table 4 Regression analysis for results of PBD screening

\begin{tabular}{|c|c|c|c|c|c|}
\hline Term & Effect & Coefficient & $\begin{array}{c}\begin{array}{c}\text { Standard } \\
\text { error }\end{array} \\
\end{array}$ & $\mathbf{t}$ & $\mathbf{P}$ \\
\hline Constant & & 0.2203 & 0.02398 & 9.19 & 0.012 \\
\hline $\mathrm{KH}_{2} \mathrm{PO}_{4}$ & 0.0010 & 0.0005 & 0.02398 & 0.02 & 0.985 \\
\hline $\mathrm{KNO}_{3}$ & $\begin{array}{c}- \\
0.1113\end{array}$ & -0.0557 & 0.02398 & -2.32 & 0.146 \\
\hline $\mathrm{MgSO}_{4} .7 \mathrm{H}_{2} \mathrm{O}$ & 0.0137 & 0.0068 & 0.02398 & 0.28 & 0.802 \\
\hline $\mathrm{CaCl}_{2} \cdot 2 \mathrm{H}_{2} \mathrm{O}$ & 0.0780 & 0.0390 & 0.02398 & 1.63 & 0.245 \\
\hline $\mathrm{C}_{10} \mathrm{H}_{12} \mathrm{FeN}_{2} \mathrm{NaO}_{8}$ & 0.0167 & 0.0083 & 0.02398 & 0.35 & 0.761 \\
\hline $\mathrm{CuSO}_{4} .5 \mathrm{H}_{2} \mathrm{O}$ & $\begin{array}{c}- \\
0.3563\end{array}$ & -0.1782 & 0.02398 & -7.43 & $\underline{0.018}$ \\
\hline $\mathrm{Na}_{2} \mathrm{MoO}_{4} \cdot 2 \mathrm{H}_{2} \mathrm{O}$ & 0.1227 & 0.0613 & 0.02398 & 2.56 & 0.125 \\
\hline Trace Metals & 0.0813 & 0.0407 & 0.02398 & 1.70 & 0.232 \\
\hline Temperature & $\begin{array}{c}- \\
0.0237\end{array}$ & -0.0118 & 0.02398 & -0.49 & 0.671 \\
\hline
\end{tabular}

$\mathrm{S}=0.0830763 \quad$ PRESS $=0.49692 \quad \mathrm{R}-\mathrm{Sq}=97.34 \% \quad \mathrm{R}-\mathrm{Sq}(\mathrm{pred})=$ $4.11 \% \quad \mathrm{R}-\mathrm{Sq}(\operatorname{adj})=85.35 \%$ 
The results show that only $\mathrm{CuSO}_{4} \cdot 5 \mathrm{H}_{2} \mathrm{O}$ was significant with a $p$-value less than 0.05 , which is confirmed in the half normal effects plot (Fig. 1) so the null hypothesis was rejected. $\mathrm{CuSO}_{4} .5 \mathrm{H}_{2} \mathrm{O}$ also had the largest coefficient and $t$-value (with effect in the negative direction). Even though the other eight variables were insignificant to the model with $p$-values above 0.05 , the overall model is significant with a $p$-value of 0.012 and the R-Sq value showed that $97.34 \%$ of the total variation was explained by the model.

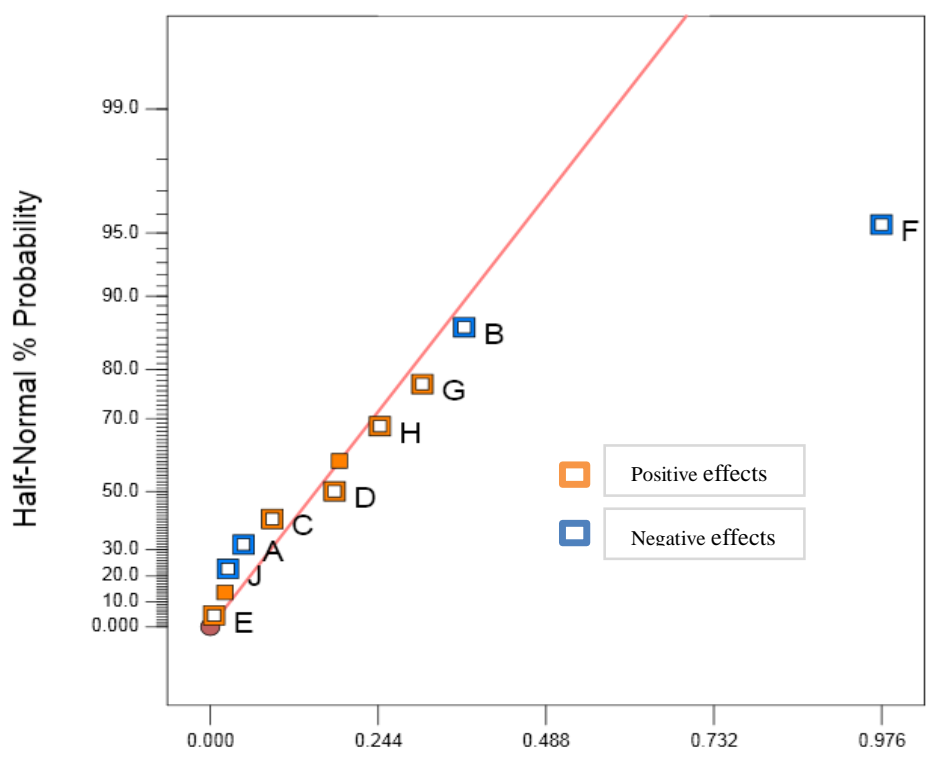

|Standardized Effect|

Figure 1 Half Normal plot of standardized effects showing significance of $\mathrm{CuSO}_{4} .5 \mathrm{H}_{2} \mathrm{O}$ (Variable F)

\section{Optimization with One Factor Response Surface Methodology}

Since only one variable was significant, the CCD could not be performed, hence OFRSM was used to determine optimal $\mathrm{CuSO}_{4} .5 \mathrm{H}_{2} \mathrm{O}$ concentration. The OFRSM run design consisted of eight runs at five concentration levels of $\mathrm{CuSO}_{4} .5 \mathrm{H}_{2} \mathrm{O}$ in the range $0.003-0.018 \mathrm{~g} / \mathrm{L}$, with two replicates at the low, center, and high concentrations (Table 5). The concentration values for the other factors were set based on the direction and size of the effect values and were kept constant throughout the OFRSM optimization trials. The average ODs obtained from the OFRSM are also shown in Table 5. The highest ODs were observed around the midpoint value of the concentration range. As seen in the response surface map (Fig. 2) showing the distribution of the data between the limits of the confidence intervals (blue dotted lines). The prediction statistics generated from the software estimated that an OD of 0.804 would result when the concentration of $\mathrm{CuSO}_{4} .5 \mathrm{H}_{2} \mathrm{O}$ is set at $0.0107 \mathrm{~g} / \mathrm{L}$. The confidence interval (CI) showed that $95 \%$ of the probable response values were contained within the interval 0.422 to 1.19 .

Table 5 OFRSM design for $\mathrm{CuSO}_{4} \cdot 5 \mathrm{H}_{2} \mathrm{O}$ at five concentration levels with $\mathrm{OD}_{540}$ responses

\begin{tabular}{lcc}
\hline Run & Concentration, $(\mathrm{g} / \mathbf{L})$ & Average $\mathbf{O D}_{\mathbf{5 4 0}}$ \\
\hline & & \\
1 & 0.003 & 0.188 \\
2 & 0.003 & 0.563 \\
3 & 0.00675 & 0.106 \\
4 & 0.0105 & 0.886 \\
5 & 0.0105 & 0.717 \\
6 & 0.0142 & 0.197 \\
7 & 0.018 & 0.045 \\
8 & 0.018 & 0.109 \\
\hline
\end{tabular}

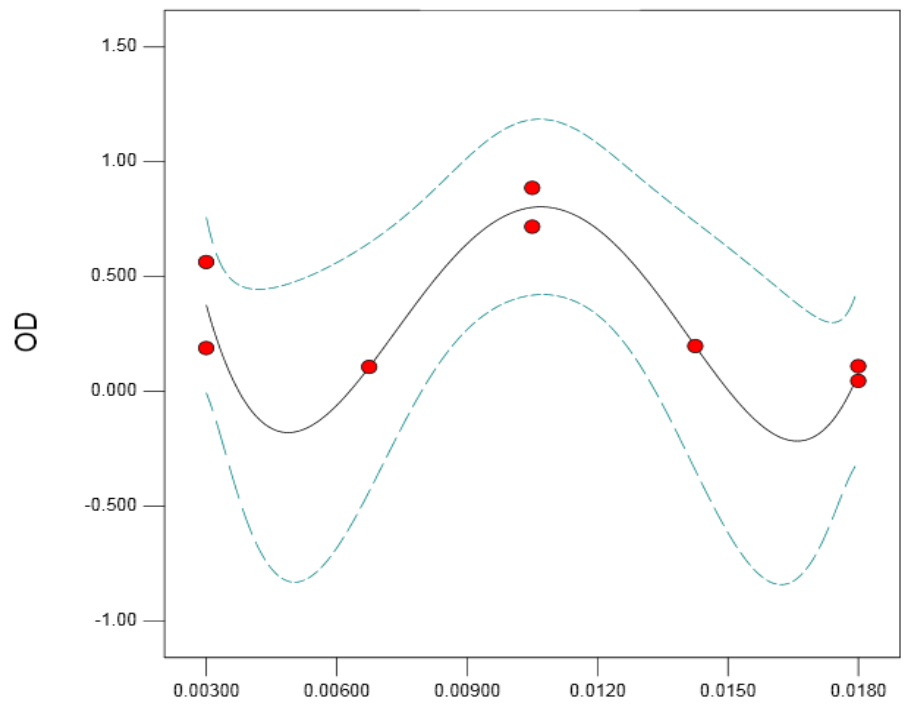

A: CuSO4

Figure 2 Response surface for $\mathrm{CuSO}_{4} .5 \mathrm{H}_{2} \mathrm{O}$ showing distribution of $\mathrm{OD}_{540}$ at the five design levels

Legend: - - _ - _ - Confidence intervals _ Surface response plot

\section{Confirmation experiments: Fed-batch fermentations}

The shake flask experiments were performed using concentration of $0.01 \mathrm{~g} / \mathrm{L}$ $\mathrm{CuSO}_{4} .5 \mathrm{H}_{2} \mathrm{O}(40 \mu \mathrm{M})$ at a temperature of $43{ }^{\circ} \mathrm{C}$. This resulted in an average OD of $0.935 \pm 0.040$ with a standard deviation (SD) of 0.057 . This result was higher than the predicted value from OFRSM but was still within the range of both the confidence and prediction intervals, showing that the model was acceptable for forecasting the result with a certain degree of accuracy. The fed-batch fermentations over 48 hours showed an average OD of 29.0 or average cell concentration of $10.30 \mathrm{~g} / \mathrm{L}$ (SD 0.24). With the un-optimized NMS medium, the average $\mathrm{OD}$ and cell concentration were 9.4 and $2.80 \mathrm{~g} / \mathrm{L}$ (SD 0.18) respectively for the same time interval. This represented a $265 \%$ increase in cell concentration based on this new concentration level for $\mathrm{CuSO}_{4} .5 \mathrm{H}_{2} \mathrm{O}$

In the fed-batch fermentations, the feed stream was typically started between OD $4-7$ when it was estimated that nutrients had become limited. In the optimized OPT run shown in Figure 3, the feed stream is started approximately 14 hours earlier than the UNOPT run, indicating a shortened lag phase due to the extra copper. The slope of the OPT run is also steeper, indicating a faster growth rate than for the UNOPT run. Another validation experiment in the fermenter was performed using the new concentration values of the other medium components with the initial un-optimized $\mathrm{Cu}^{2+}$ concentration value $(0.00256 \mathrm{~g} / \mathrm{L})$. The resulting cell concentration was $5.60 \mathrm{~g} / \mathrm{L}(\mathrm{SD} 0.70)$, a $100 \%$ increase from the initial value of $2.80 \mathrm{~g} / \mathrm{L}$. This means that the overall increase in cell concentration was also affected by changes in values of the other factors. However, the medium composition was still limiting since the increase in copper allowed growth to further increase to $10.30 \mathrm{~g} / \mathrm{L}$ for the same number of fermentation hours.

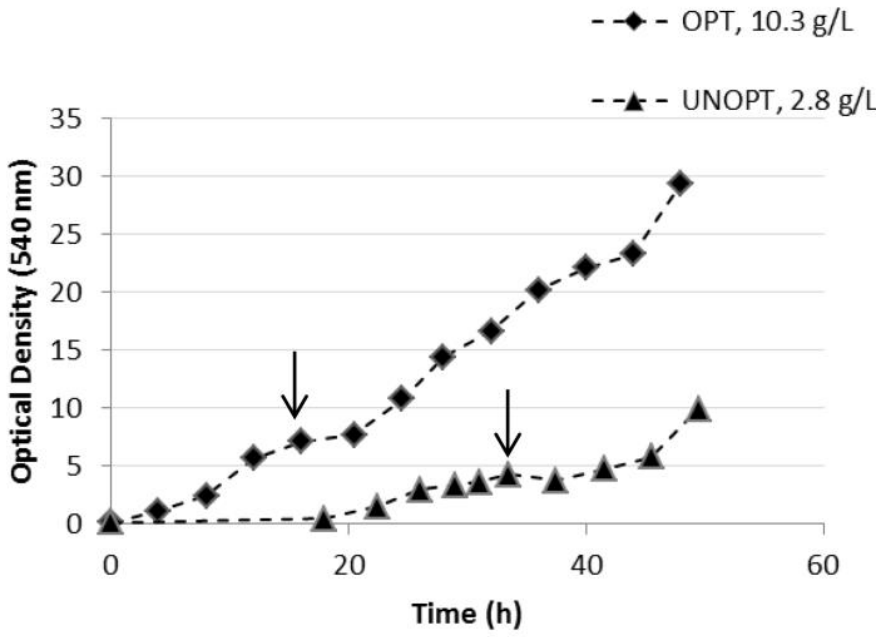

Figure 3 OD over 48 hours for fed-batch mixed culture Legend: Before (UNOPT) and after (OPT) optimization. Arrows indicate where feed-streams were started. 


\section{Heterotrophic bacteria}

All three bacteria demonstrated no growth on the NMS medium with $\mathrm{CH}_{4}$ as carbon source but showed excellent growth in shake flasks in complex media when OD $540 \mathrm{~nm}$ was measured after 24 hours (A. acidovorans, 3.145; A danicus, 1.823 ; Brevibacillus sp., 1.531). If the heterotrophs were $\mathrm{CH}_{4}$ dependent, their growth would likely outpace that of $M$. capsulatus (Bath) since growth rates for the heterotrophs on acetate ranged from $0.45 h^{-1}-0.6 h^{-1}$ (Stanley \& Dalton, 1982) while the maximum growth rate recorded for $M$. capsulatus (Bath) in a monoculture was $0.37 \mathrm{~h}^{-1}$ (Joergensen \& Degn, 1987). Therefore the requirement for extra $\mathrm{Cu}^{2+}$ in the medium is not a requirement for heterotrophic growth but rather, it is necessary for optimal growth of $M$. capsulatus (Bath). When the three heterotrophs were combined with $M$. capsulatus (Bath), the OD increased from $0.349 \pm 0.52$ SD before addition to $0.807 \pm 0.032$ SD under the same conditions. The contribution of the heterotrophic cells to the overall OD in shake flasks was not determined.

It is well known from previous studies that the amount of copper in the medium influences the expression of either the soluble (sMMO) or particulate (pMMO) forms of Methane monooxygenase (Prior \& Dalton, 1985; Semrau et al., 1995) with the pMMO being activated at $\mathrm{Cu}^{2+}$ concentrations greater than $1.5 \mu \mathrm{M}$ Zhivotchenko et al. ,1995; Stanley et al., 1983. In the un-optimized medium used in this study, the $\mathrm{Cu}^{2+}$ concentration was $11 \mu \mathrm{M}$ which indicates that the pMMO was already activated. However, the significant increase in growth when copper was increased to $40 \mu \mathrm{M}$ in the optimized medium suggests that even though the pMMO was active, the $\mathrm{Cu}^{2+}$ concentration was still limiting. Zhivotchenko et al. (1995) indicated that $6 \mu \mathrm{M} \mathrm{Cu}^{2+}$ is the optimum level required for every $1 \mathrm{~g} / \mathrm{L}$ biomass. Using this correlation for $10.30 \mathrm{~g} / \mathrm{L}$ biomass concentration resulting from this study, the $\mathrm{Cu}^{2+}$ requirement would be approximately $62 \mu \mathrm{M}(0.015 \mathrm{~g} / \mathrm{L})$. This concentration was investigated in the range of the OFRSM experiments in shake flasks but was not found to be optimal. This suggests that the relationship between biomass concentration and copper requirement is not a simple linear relation as the previous study suggests From the data generated in this study, and assuming that $6 \mu \mathrm{M} \mathrm{Cu}^{2+}$ is required for $1 \mathrm{~g} / \mathrm{L}$ biomass; the $\mathrm{Cu}^{2+}$ requirement can be modeled according to:

$\left[C u^{2+}\right]=e^{\left(\frac{[X]+6.72}{4.70}\right)}$

The heterotrophic bacteria used for the mixed culture fermentations used previously by Norferm Danmark A/S was not planned but was found to be a necessary addition to the process. Their contribution to the cell population during batch culture was estimated by microscopic analysis to be approximately $5 \%$ of the cell population at an approximate cell concentration of $1 \mathrm{~g} / \mathrm{L}$. At Norferm Danmark A/S, the final heterotroph population, which was likely determined after extended continuous production runs, ranged between $13 \%-19.8 \%$ of the total cell population, depending on the composition of natural gas used (Bothe $\boldsymbol{e}$ al., 2002). The activity of the heterotrophic bacteria as a function of dissolved oxygen concentration may help elucidate the function of these bacteria during different phases of the fermentation Although the heterotrophs can function as natural gas oxidation product scavengers, their main purpose seems to be scavenging of dead cells since oxygen becomes limiting at higher cell concentrations resulting in less oxidation by-products of natural gas but increasing numbers of cells in death phase. The mixed culture growth is a complex process since the heterotrophs do not grow on NMS. Hence, modeling would have to include monitoring of production and consumption rates of all metabolic products during fermentation, natural gas oxidation products, and monitoring of cell population and viability, both as a consortium and individually

Surprisingly, despite its crucial role in cell energetics, phosphate concentration was not a significant factor. Although calcium was also insignificant, the effect value dictated that a higher value was preferred so the concentration was increased to the mid-range value. $\mathrm{Ca}^{2+}$ is known to have an important role in the active sites of Methanol Dehydrogenase (MDH) and the MMO, allowing the prosthetic group pyrrolo-quinoline quinone (PQQ) to maintain the correct configuration for its role in substrate oxidation. The concentration of $\mathrm{MoO}_{4}{ }^{2-}$ was doubled for similar reasons and this is understandable since molybdenum is an important element for biological processes. Overall, the statistical optimization allowed the system to be examined as a whole, and combined with the other changes to the media, this method worked well for detecting the optimum operating levels.

The impact of other fermentation parameters on cell density needs to be further investigated since the biomass concentration also depends on the availability of dissolved oxygen and methane. At low cell densities, these substrates are present in excess but as cell density increases, oxygen and methane become limiting. However, it is highly possible that the cultures in this study were grown under oxygen limitation since similar methanotrophic organisms have exhibited substrate inhibition as dissolved oxygen increased (Wendlandt, Jechorek, \& Bruhl, 1993). The optimal agitation and gas supply rates need therefore to be investigated, and the point at which mass transfer becomes limiting needs to be determined for the overall optimization of this bioprocess.

\section{CONCLUSION}

The medium components for biomass production from a mixed culture of $M$ capsulatus (Bath) and three heterotrophic bacteria were screened by PBD and optimized with OFRSM. The use of these two experimental design techniques allowed for investigation of multiple process parameters in a condensed format. By using these tools, the optimum level of $\mathrm{Cu} 2+$ was found, but its effect at various concentrations could also be observed on the surface response map. The increase in growth rates and the almost tripled cell concentrations observed using the optimized medium shows the important role of copper in the operation of the methane oxidation enzyme systems. The complex nature of the heterotrophic synergy needs further investigation to fully understand their specific role in $M$. capsulatus (Bath) fermentations.

\section{REFERENCES}

ALEXANDRATOS, N., \& BRUINSMA, J. (2012). World Agriculture Towards 2030/2050: The 2012 revision. ESA working paper12-03. Rome: Food and Agriculture Organization of the United Nations (FAO), Agriculture Development Economics Division, http://www.fao.org/docrep/016/ap106e/ap106e.pdf.

ATTARCHI, N., MONTAZER, M., \& TOLIYAT, T. (2013). Ag/TiO $/ \beta-C D$ Nanocomposite: Preparation and Photocatalytic properties for methylene blue degradation. Appl. Catal. A, Gen. 467, 107-116. http://dx.doi.org/10.1016/japcata.2013.07.018

BOTHE HAR., MOLLER JENSEN, K., MERGEL, A., LARSEN, J., JORGENSEN, C., BOTHE HER., \& JORGENSEN, L. (2002). Heterotrophic bacteria growing in association with Methylococcus capsulatus (Bath) in a single cell protein production process. Appl. Microbiol. Biotechnol. 59, 33-39. http://dx.doi.org/10.1007/s00253-002-0964-1

CARLSEN, H. N., JOERGENSEN, L., \& DEGN, H. (1991). Inhibition by Ammonia of Methane Utilization in Methylococcus capsulatus (Bath). Appl. Microbiol. Biotechnol. 35,124-127. http://dx.doi.org/10.1007/BF00180649

COOKE, M., DAWSON, M.K., NIENOW, A.W., MOODY, G.W., \& WHITTON, M.J. (1991). Mass transfer in aerated agitated vessels: Assessment of the NEL/Hickman steady state method. Proc. 7th Eur. Conf. Mixing, pp. 409-418 DALTON, H., \& WHITTENBURY, R. (1976). The Acteylene Reduction Technique as an Assay for Nitrogenase Activity in the Methane Oxidizing Bacterium Methylococcus capsulatus Strain Bath. Arch. Microbiol. 109, 147-151. http://dx.doi.org/10.1007/BF00425127

ECCLESTON, M., \& KELLY, D.P. (1972). Assimilation and Toxicity of Exogenous Amino Acids in the Methane Oxidizing Bacterium Methylococcus capsulatus. J. Gen. Microbiol. 71, 541-554. http://dx.doi.org/10.199/0022128773-2-303

FOSTER, J.W., \& DAVIS, R.H. (1966). A methane dependent coccus with notes on classification and nomenclature of obligate, methane utilizing bacteria. $J$. Bacteriol. 91, $1924-1931$

FURIGO JR., A., \& JORGENSEN, M.H. (1993). Nitrogen limited growth of a $\begin{array}{lllll}\text { methanotrophic culture. Bioprocess } & \text { Eng. } & \text { 9, 119-127. }\end{array}$ http://dx.doi.org/10.1007/BF00369041

HARRISON, D. E. F. (1978). Mixed Cultures in Industrial Fermentation Processes. Adv. Appl. Microbiol. 24, 129-164

HARWOOD, J.H. \& PIRT, S.J. (1972). Quantitative aspects of growth of the methane oxidizing bacterium Methylococcus capsulatus on methane in shake flask and continuous chemostat culture. J. Appl. Bacteriol. 35, 597-607. http//dx.doi.org/10.1111/j.1365-2672.1972.tb03741.x

HICKMAN, A.D. (1988). Gas-liquid oxygen transfer. A novel experimental technique with results for mass transfer in aerated agitated vessels.Proc. 6th Eur. Conf. Mixing, Pavia, 369-374

CHEN, J., HUANG, P.T., ZHANG, K.Y., \& DING, F.B. (2012). Isolation of biosurfactant producers, optimization and properties of biosurfactants produced by Acinetobacter sp. from petroleum-contaminated soil. J. Appl. Microbiol. 112 (4), 660-671. http://dx.doi.org/10.1111/j.1365-2672.2012.05242.x

JEIRANI, Z., JAN, B.M., ALI, B.S., NOOR, I.M., SEE, C.H., \& SAPHANUCHART, W. (2013). Prediction of water and oil percolation thresholds of a micro-emulsion by modeling of dynamic viscosity using Response Surface Methodology. J. Industrial Eng. Chem. 19, 554-560. http://dx.doi.org/10.1016/j.jiec.2012.09.027

JEONG, J-H., KIM, J-N., WEE, Y-J., \& RYU, H-W. (2010). The statistically optimized production of poly ( $\gamma$-glutamic acid) by batch fermentation of a newly isolated Bacillus subtilis RKY3. Bioresour. Technol. 101, 4533-4539. http://dx.doi.org/10.1016/j.biortech.2010.01.080

KENNEDY, M., \& KROUSE, D. (1999). Strategies for improving fermentation medium performance: A review. J. Industrial. Microbiol. Biotechnol. 23, 456475. http://dx.doi.org/10.1038/sj.jim.2900755

KHURI, A.I., \& MUKHOPADHYAY, S. (2010). Response Surface Methodology. WIREs Comp. Stat. 2, 128-149. http://dx.doi.org/10.1002/wics.73 KOSMIDER, A., BIALAS, W., KUBIAK, P., DROZDZYNSKA, A., \& CZACZYK, K. (2012). Vitamin B12 production from crude glycerol by Propionibacterium freudenreichii sp. Shermanii: Optimization of medium 
composition through statistical experimental designs. Bioresour. Technol. 105, 128-133. http://dx.doi.org/10.1016/j.biortech.2011.11.074

LARSEN, J., \& JOERGENSEN, L. (1996). Reduction of RNA and DNA in Methylocccus capsulatus by endogenous nucleases. Appl. Microbiol. Biotechnol. 45, 137-140. http://dx.doi.org/10.1007/s002530050661

LEAK, D.J., \& DALTON, H. (1986). Growth Yields of Methanotrophs I: Effect of copper on energetics of methane oxidation. Appl. Microbiol. Biotechnol. 23, 470-476. http://dx.doi.org/10.1007/BF02346062

LI, X., OUYANG, J., SONG, M., CHEN, X., YONG, Q., \& YU, S. (2009) Optimization of culture conditions for production of yeast biomass using bamboo wastewater by Response Surface Methodology. Bioresour. Technol. 100, 3613 3617. http://dx.doi.org/10.1016/j.biortech.2009.03.001

LINTON, J.D., \& BUCKEE, J.C. (1977). Interactions in a Methane-utilizing Mixed Bacterial Culture in a Chemostat. J. Gen. Microbiol. 101, 219-255. http://dx.doi.org/10.1099/00221287-101-2-219

MANWAR, J., MAHADIK, K., \& PARADKAR, A. (2013). Plackett-Burman design: A statistical method for optimization of fermentation process for the yeas Saccharomyces cerevisiae isolated from the flowers of Woodfordia fructicosa. Ferment. Technol. 2(1), 109. http://dx.doi.org/10.4172/2167-7972.1000109

MOKHTARI-HOSSEINI, Z.B., VASHEGHANI-FARAHANI, E., HEIDARZADEH-VAZIFEKHORAN, A., SHOJAOSADATI, S.A., KARIMZADEH, R.. \& DARANI, K.K. (2009). Statistical Medium Optimization for Growth and PHB production from methanol by a methylotrophic bacterium. Bioresour. Technol. 100, 2436-2443. http://dx.doi.org/10.1016/j.biortech.2008.11.024

PRIOR, S.D., \& DALTON, H. (1985). The effect of copper ions on membrane content and methane monooxygenease activity in methanol grown cells of Methylococcus capsulatus (Bath). J. Gen. Microbiol. 131, 155-163. http://dx.doi.org/10.1099/00221287-131-1-155

SEMRAU, J.D., ZOLANDZ, D., LIDSTROM, M.E., \& CHAN, S.I. (1995). The role of copper in the pMMO of Methylococcus capsulatus Bath: A structural vs. catalytic function. J. Inorg. Biochem. 58, 235-244 http://dx.doi.org/10.1016/0162-0134(94)00056-G

STANLEY, S.H., \& DALTON, H. (1982). Role of Ribulose-1,5-bisphosphate carboxylase/oxygenase in Methylococcus capsulatus (Bath). J. Gen. Microbiol. 128, 2927-2935. http://dx.doi.org/10.1099/00221287-128-12-2927

STANLEY, S.H., PRIOR, S.D., LEAK, D.J., \& DALTON H. (1983). Copper Stress Underlies the Fundamental Change in Intracellular Location of Methane Mono-Oxygenase in Methane Oxidising Organisms: Studies in Batch and Continuous Cultures.Biotechnology Letters, 5 (7), 487-492. http://dx.doi.org/10.1007/BF00132233

UNITED NATIONS, Department of Economic and Social Affairs Population Division. 203. World Population prospects, The 2012 Revision: Key findings and advance tables. Working Paper No. ESA/P/WP.227

WALIA, N.K., SEKHON, K.K., CHAUDHARY, D.P., CAMEOTRA, S.S. SRIVASTAVA, P., \& KUMAR, A. (2014). Optimization of fermentation parameters for bioconversion of corn to ethanol using Response Surface $\begin{array}{lllll}\text { Methodology. Pet. \& Environ. Biotechnol. } & \text { 5(3), } 178\end{array}$ http://dx.doi.org/10.4172/2157-7463.10000178

WHITTENBURY, R., PHILLIPS, K.C., \& WILKINSON, J.F. (1970). Enrichment, Isolation and some properties of Methane-utilizing bacteria. J. Gen Microbiol. 61, 205-218. http://dx.doi.org/10.1099/00221287-61-2-205

YATSYSHYN, V.Y., FEDOROVYCH, D.V., \& SIBIRNY, A.A. (2010) Medium optimization for production of flavin mononucleotide by the recombinant strain of the yeast Candida famata using statistical design. Biochem. Eng. 49, 52-60. http://dx.doi.org/ 10.1016/j.bej.2009.11.010

ZARATE-CHAVES, C.A., ROMERO-RODRIGUEZ, M.C., NINO-ARIAS F.C., ROBLES-CAMARGO, J., LINARES-LINARES, M., RODRIGUEZBOCANEGRA, M.X., \& GUTIERREZ-ROJAS, I. (2013). Optimizing a culture medium for biomass and phenolic compounds production using Ganoderma lucidum. Brazilian J. Microbiol. 44(1), 215-223. http://dx.doi.org/10.1590/S1517-83822013005000032

ZHANG, C., ZHANG, Y., ZHUANG, B., \& ZHOU, X. (2014). Strategic enhancement of algal biomass, nutrient uptake, and lipids through statistica optimization of nutrient supplementation in coupling Scendesmus obliquus-like microalgae cultivation and municipal wastewater treatment. Bioresour. Technol. 171, 71-79. http://dx.doi.org/10.1016/j.biortech.2014.07.060

ZHIVOTCHENKO, A.G., NIKONOVA, E.S., \& JORGENSEN, M.H. (1995)

Copper effect on growth kinetics of Methylococcus capsulatus (Bath) Biotechnology Techniques. 9(3), 163-168. http://dx.doi.org/10.1007/BF00157072 